Article

\title{
Low-Carbon Supply Chain Model under a Vendor-Managed Inventory Partnership and Carbon Cap-and-Trade Policy
}

\author{
Ririn Diar Astanti *, Yosef Daryanto *(D) and Parama Kartika Dewa \\ Department of Industrial Engineering, Universitas Atma Jaya Yogyakarta, Yogyakarta 55281, Indonesia; \\ parama.dewa@uajy.ac.id \\ * Correspondence: ririn.astanti@uajy.ac.id (R.D.A.); yosef.daryanto@uajy.ac.id (Y.D.)
}

Citation: Astanti, R.D.; Daryanto, Y.; Dewa, P.K. Low-Carbon Supply Chain Model under a Vendor-Managed Inventory Partnership and Carbon

Cap-and-Trade Policy. J. Open Innov. Technol. Mark. Complex. 2022, 8, 30. https://doi.org/10.3390/joitmc 8010030

Received: 10 November 2021

Accepted: 15 January 2022

Published: 25 January 2022

Publisher's Note: MDPI stays neutral with regard to jurisdictional claims in published maps and institutional affiliations.

Copyright: (C) 2022 by the authors. Licensee MDPI, Basel, Switzerland. This article is an open access article distributed under the terms and conditions of the Creative Commons Attribution (CC BY) license (https:// creativecommons.org/licenses/by/ $4.0 /)$.

\begin{abstract}
Nowadays, companies are collaborating and forming supply chain partnerships under a certain scheme, such as a vendor-managed inventory scheme. The collaboration increases the supply chain's visibility, which leads to cost efficiency. It may also contribute to enhancing the supply chain's green performance. This paper presents a supply chain inventory model to guide managers in making optimal inventory decisions considering the logistics cost and carbon emissions. A vendor supplies products under a vendor-managed inventory; hence, it is responsible for the logistics activities. The effect of product deterioration and quality problems are also considered, in which the vendor performs a $100 \%$ quality inspection. A carbon price is imposed on total emissions from production and logistics activities under a cap-and-trade regulation. The result is inventory decisions regarding the optimal delivery quantity as well as the delivery frequencies that minimize the total costs. The reduction in total carbon emissions from the decisions was also studied.
\end{abstract}

Keywords: vendor-managed inventory; cap-and-trade; carbon emission; deterioration; imperfect quality

\section{Introduction}

Logistics and supply chain systems are pillars of industrial development and affect national competitiveness. Supply chain practitioners and researchers innovate supply chain structures and optimize their decisions to minimize costs. For example, the level of replenishment of products with suitable inventory policies plays an important role in minimizing the supply chain cost; hence, they are solved using optimization or heuristics approaches [1-3].

One of the focuses in current logistics system development research is building a logistics system that is environmentally friendly within the framework of sustainable development. In particular, global awareness of climate change has inspired so-called low-carbon supply chain management to minimize the $\mathrm{CO}_{2}$ emissions of the supply chain $[4,5]$. The carbon footprint measures the total amount of $\mathrm{CO}_{2}$ emissions sourced from the production and logistics activities until the consumption and disposal or recycling of the products. Researchers factor in the costs of carbon emissions in their supply chain decision models. A direct accounting approach is widely used to translate environmental aspects of carbon emissions into economic parameters [6,7]. Wahab et al. [8] considered emission costs from transportation activities between vendors and buyers while Hariga et al. [9] focused on cold product supply chains. Tiwari et al. [10] and Daryanto et al. [11] studied the level of quality of the production output and deterioration rate (the rate of deterioration in the number of products) in supply chain decision-making that considers the emission level. The studies above take into account the cost of emissions based on the carbon tax regulation.

A supply chain partnership, such as a vendor-managed inventory (VMI), is an example of a collaboration practice that reduces the inventory cost and brings about delivery flexibility through information sharing. This partnership increases the demand visibility, coordination, and cost-sharing, which leads to cost efficiency due to better planning [12,13]. 
Daryanto and Krämer [14] illustrated a VMI partnership between a paint manufacturer (supplier) and a corrugated box manufacturer (buyer). Recently, Kumar and Uthayakumar [15] and Turken et al. [16] incorporated the effect of a carbon cap-and-trade regulation in a supply chain with a VMI. However, they did not consider the effect of imperfect quality and deterioration. Agricultural, food, and chemical products are examples of deteriorating products with some potential for imperfect quality to occur during their production. This gap motivates our research because these factors, together with a supply chain partnership program such as a VMI, affect the cost structure between the vendor and the buyer in a supply chain; hence, optimal decisions are required.

In this research, a vendor-managed inventory partnership is applied between a vendor and a buyer. The delivery size and frequencies per cycle decisions affect the production and logistics activities. The production, transportation, and inventory levels determine the total costs and emissions [11,12]. In particular, this study proposes a new model by simultaneously considering the effect of defect rate, deterioration rate, vendor-managed inventory partnership model, and carbon emissions in terms of $\mathrm{CO}_{2}$. The $\mathrm{CO}_{2}$ is emitted directly during the production and transport of the products, and indirectly when holding the inventory. Our literature study indicates that there is no previous research that considers all these factors simultaneously. This research studies the influence of these factors on the minimization of costs and levels of carbon emissions from the supply chain. The results can be used as a guide for managerial decisions to develop a profitable and sustainable supply chain system.

The remainder of this paper is structured as follows. We present a review of related studies in Section 2. Section 3 defines the notation and assumptions of the proposed model. Section 4 presents the mathematical model's development. Section 5 provides a numerical example together with a discussion of the results, including some managerial insights. Finally, Section 6 gives the conclusions and some ideas for further studies.

\section{Literature Review}

\subsection{Integrated Supply Chain Inventory Model}

Typically, supply chain members collaborate and make a joint inventory decision to maximize profits or minimize supply chain costs. Previous studies show that this collaboration can benefit all parties [17,18]. The cooperation involves at least two parties, such as vendors (manufacturers or wholesalers) and buyers (other manufacturers, retailers, consumers, and others). This collaboration is implemented in various models, for example with a vendor-managed inventory where the vendor is responsible for managing the buyer's inventory in a long-term partnership. In this collaboration, vendors can fully understand the needs of buyers while buyers only pay for the products they consume [19-21].

The supply chain inventory model considers the various costs that arise. Transportation costs are an important and influential part. Nie et al. [22] consider product weight and delivery quantity for supply chain transportation costs. Ertogral et al. [23] also use transportation costs, which are a function of the size of the shipment, and consider the effect of discounts. Sarkar [24] uses a fixed transportation cost per shipment and different handling costs per unit in a supply chain with a single-setup multiple-delivery approach.

Supply chain inventory models that take into account the effects of imperfect product quality have been studied for many years. Some researchers assume that defective products will be taken from the buyer's inventory and sold at a lower price [25]. Others, such as Bazan et al. [26] and Sarkar et al. [27], assume that the vendor (manufacturer) runs the inspection process. Furthermore, defective products can be reworked.

Many researchers have also considered the effect of the deterioration rate on supply chain models [28-30]. Some types of products, such as fruits, vegetables, and paper, deteriorate in quality during the storage period, while most electronic products experience a decline in value due to their short life span. Lee and Kim [25] studied the effects of deterioration and imperfect quality in their supply chain model. Chan et al. [31] studied the effect of deterioration and variable production rates. 


\subsection{Low-Carbon Supply Chain Management}

Global awareness of climate change and concern for preserving the environment have inspired many researchers, industries, and other organizations to develop supply chain systems that are environmentally friendly and can minimize carbon emissions (low-carbon supply chain management) from their activities [4,5]. For example, transportation activities are a large source of carbon emissions and have the potential to be a contributor to global warming in supply chains [32].

Wahab et al. [8] examined a two-level international supply chain by considering the effect of transportation to reduce $\mathrm{CO}_{2}$ emissions. Jauhari et al. [33] considered carbon emissions from transportation activities in the supply chain with variable delivery sizes and the effect of defective products. Emission costs arise from both shipping to the buyer and returning the defective product to the vendor. Zanoni et al. [34] developed a model to determine the size of shipments, the number of shipments, selling prices, and investments to improve the environmental performance of its products. These studies add the cost of carbon emissions to the overall system cost under the carbon tax rule. In general, the carbon tax acts as a penalty for the industry because it produces emissions from its activities [35]. Hammami et al. [36] include emissions from warehouses, production facilities, and transportation in a multi-level supply chain model. Sarkar et al. [37] use both fixed and variable transportation costs and emissions in a three-level supply chain. Wangsa [38] considers carbon emissions from production, transportation, and material handling activities. Focusing on the supply chain for cold products, Hariga et al. [9] studied the cost savings and emissions reductions of an integrated supply chain model. Cold products require special refrigerated trucks and warehouses; so, they consume more fuel and electrical energy. Further, Bouchery et al. [39] included vehicle capacity constraints to examine the effect on costs and emissions, while Paul [40] considered investments in green operations for reducing emission levels.

Tiwari et al. [10] developed an integrated supply chain model that considers deterioration rate, imperfect quality, and carbon emissions from transportation, storage, and deteriorated items. Furthermore, Daryanto et al. [11] developed a model by comparing the inspections carried out by vendors and buyers and their effects on costs and emissions. Daryanto et al. [41] and Wee and Daryanto [42] considered emissions from storage, transportation, and waste disposal. Recently, Wangsa et al. [43] included emissions from material handling activities during inbound and outbound logistics between vendor and buyer, while Daryanto and Wee [44] developed an inventory model in the supply chain by considering emission costs from the warehouse and transportation, especially in a three-level supply chain.

Carbon cap-and-trade is a type of carbon pricing regulation that has been implemented in many countries and studied by scholars such as Zanoni et al. [21,34], Kumar and Uthayakumar [15], and Hasan et al. [45]. Marchi et al. [46] developed an integrated supply chain model that considers a vendor-managed inventory, imperfect quality, and cap-and-trade regulation. Bai et al. [12] developed a similar integrated supply chain model with a vendor-managed inventory but for deteriorating items. Considering the latest two studies, our proposed model simultaneously considers the effect of defect rate, deterioration rate, vendor-managed inventory partnership model, and carbon cap-and-trade. Defective products are treated similarly to Daryanto et al. [41] and the sources of emissions are similar to Bai et al. [12] and Daryanto and Wee [44]. A summary of the literature review is presented in Table 1. 
Table 1. Literature review and gap analysis summary.

\begin{tabular}{|c|c|c|c|c|}
\hline Author & $\begin{array}{l}\text { Imperfect } \\
\text { Quality }\end{array}$ & Deterioration & $\begin{array}{l}\text { Vendor- } \\
\text { Managed } \\
\text { Inventory }\end{array}$ & $\begin{array}{l}\text { Carbon Cap- } \\
\text { and-Trade }\end{array}$ \\
\hline Rau et al. [28] & & Yes & & \\
\hline Gunasekaran et al. [6] & & & & Yes \\
\hline Bazan et al. [26] & Yes & & Yes & \\
\hline Zanoni et al. [21] & & & Yes & Yes \\
\hline Zanoni et al. [34] & & & & Yes \\
\hline Lee and Kim [25] & Yes & Yes & & \\
\hline Sarkar et al. [37] & Yes & & & \\
\hline Sarkar et al. [27] & Yes & & & \\
\hline Chan et al. [31] & & Yes & & \\
\hline Wangsa [38] & Yes & & & \\
\hline Tiwari et al. [10] & Yes & Yes & & \\
\hline Daryanto et al. [11] & Yes & Yes & & \\
\hline Daryanto et al. [41] & & Yes & & \\
\hline Marchi et al. [46] & Yes & & Yes & Yes \\
\hline Bai et al. [12] & & Yes & Yes & Yes \\
\hline Kumar and Uthayakumar [15] & & & Yes & Yes \\
\hline Wee and Daryanto [42] & Yes & & & \\
\hline Hasan et al. [45] & & & & Yes \\
\hline Turken et al. [16] & & & Yes & Yes \\
\hline Daryanto and Wee [44] & Yes & Yes & & \\
\hline This study & Yes & Yes & Yes & Yes \\
\hline
\end{tabular}

\subsection{Open Innovation and Vendor-Managed Inventory}

Currently, competition in the business world is no longer a competition between one company and another. The competition in the business world today is a competition between a company and its entire supply chain and other companies and their entire supply chain [47]. To win the competition, companies must carry out activities in their business processes more efficiently. To find more efficient ways of carrying out activities in the business process, innovation is needed [48].

Innovation is an important factor that supports the success of a company so that it has a competitive advantage [49-51]. In the supply chain, there are interactions between several parties, including suppliers, manufacturers, and distributors. The open innovation concept states that innovation is not owned by only one party, but by many parties, including consumers, suppliers, and competitors [52].

Studies regarding the application of open innovation have been carried out in the product development area [49,53]. In addition, research on business models and open innovation in the car-sharing industry has also been carried out [54]. Research on the relationship between eco-innovation and open innovation in the supply chain has also been carried out $[55,56]$. Open innovation in SMEs has also attracted the attention of researchers [57-62].

One of the factors that influences the collaborative innovation capability is trust [63-65]. In addition, information sharing in a supply chain with a vendor-managed inventory [66] is also an important factor for accelerating open innovation [47].

\section{Notation and Assumptions}

The following notation is used in this study:

Parameters:

$D$ demand rate (unit/year).

$r$ production rate (unit/year).

$\theta \quad$ deterioration rate $(0 \leq \theta<1)$

$u$ the rate of defective products $(E[u]$ is the expected value of $u)$. 
$i_{c} \quad$ inspection cost (\$/unit)

c buyer's setup cost per cycle (\$/cycle).

$h_{b} \quad$ holding cost at buyer's storage facility (\$/unit/year).

$d_{b} \quad$ deterioration cost at buyer's storage facility ( $\$ /$ unit).

$s \quad$ vendor's production setup cost (\$/order).

$h_{v} \quad$ holding cost at vendor's storage facility (\$/unit/year).

$d_{v} \quad$ deterioration cost at vendor's storage facility (\$/unit).

$d \quad$ distance traveled by a truck $(\mathrm{km})$.

$W$ product weight (ton/unit).

$T_{f} \quad$ fixed transportation cost for a truck (\$/delivery).

$T_{v} \quad$ variable transportation cost, which depends on fuel consumption (\$/liter).

$c_{1}$ fuel consumption of an empty truck (liters $/ \mathrm{km}$ ).

$c_{2}$ fuel consumption per ton of truckload (liters $/ \mathrm{km} / \mathrm{ton}$ ).

$c_{3}$ energy consumption for storing a product $(\mathrm{kWh} /$ unit/year).

$E_{c} \quad \mathrm{CO}_{2}$ emission cap (ton $\mathrm{CO}_{2}$ ).

$E_{P} \quad \mathrm{CO}_{2}$ emission price $\left(\$ /\right.$ ton $\left.\mathrm{CO}_{2}\right)$.

$F_{e} \quad \mathrm{CO}_{2}$ emissions from vehicle fuel (ton $\mathrm{CO}_{2} /$ liter).

$E_{e} \quad \mathrm{CO}_{2}$ emissions from electricity (tonCO $\mathrm{C}_{2} / \mathrm{kWh}$ ).

$P_{e} \quad \mathrm{CO}_{2}$ emissions from production processes (tonCO $\mathrm{C}_{2} /$ unit).

Decision variables:

$n \quad$ number of deliveries.

$T_{2}$ nonproduction period of the manufacturer (year).

Other variables:

$Q \quad$ delivery quantity (unit).

$T$ cycle length (years).

$T_{1} \quad$ production period of the manufacturer (years).

$T_{b} \quad$ delivery cycle length (years).

$P \quad$ production quantity per cycle (unit).

$I_{v}(t)$ inventory level at vendor's storage facility at time $t$.

$I_{d}(t)$ inventory level of defective products at time $t$.

$I_{b}(t)$ inventory level at buyer's storage facility at time $t$.

$T C_{b}$ annual total cost of the buyer (\$/year).

$T C_{v}$ annual total cost of the vendor (\$/year).

TC annual total cost of the supply chain (\$/year).

$\mathrm{TE}_{b}$ annual carbon emissions of the buyer (ton $\mathrm{CO}_{2} /$ year).

$T E_{v}$ annual carbon emissions of the vendor (ton $\mathrm{CO}_{2} /$ year).

$T E$ total carbon emissions per year (tonCO $\mathrm{C}_{2} /$ year).

The proposed model works under several assumptions:

1. Similarly to Zanoni [21], Bazan [26], and Marchi [46], demand is known and has a constant rate. Demand information is shared with the vendor under the vendormanaged inventory partnership. For example, the production plan of a corrugated box manufacturer is shared with its ink vendor so that the demand is manageable.

2. Under this partnership, the vendor needs to ensure that there is no shortage at the buyer's storage facility. Therefore, the production rate of good-quality products is equal to or greater than the demand rate [21].

3. The vendor delivers $n$ equal lot sizes per production cycle.

4. The deterioration rate is constant. The rate at the vendor's and buyer's storage facility is the same. However, the deterioration cost at the buyer's storage facility is higher due to the product value $\left(d_{b}>d_{v}\right)$.

5. Due to production reliability issues, the vendor must perform a quality inspection to eliminate the possibility of delivering defective products to the buyer's storage facility. Defective products will not be reworked or repaied and they will be sold to a different market. Defective products follow a uniform distribution where $0 \leq \alpha<\beta<1$, similar to Daryanto et al. [41] and Daryanto and Wee [44]. 
6. Fuel consumption is a linear function of truckloads, similar to Hariga et al. [9] and Daryanto et al. [41].

7. The government's carbon cap-and-trade regulation is applied to the total carbon emitted by the supply chain. $\mathrm{CO}_{2}$ is produced during the production, storage, and transport of items.

\section{Model Development}

The proposed model considers a supply chain partnership between a manufacturer (vendor) that supplies one type of product to another manufacturer (or retailer) that acts as the buyer. The vendor needs to maintain the inventory level at their own storage facility as well as at the buyer's storage facility because the holding costs are their responsibility. Because transportation costs are also the vendor's responsibility, it needs to determine the optimal quantity and time to deliver the product and the optimal production quantity. The vendor implements single-setup multiple deliveries (SSMD) by delivering $n$ equal lot sizes $(Q)$ per cycle. It produces $n Q$ units of items per production cycle. The following part of this section provides the model development.

The inventory level at the vendor's and buyer's facilities, including the defective products, can be seen in Figure 1 . The vendor stores the defective products until $T_{1}$. Then, they will be sold at a lower price to a different market.

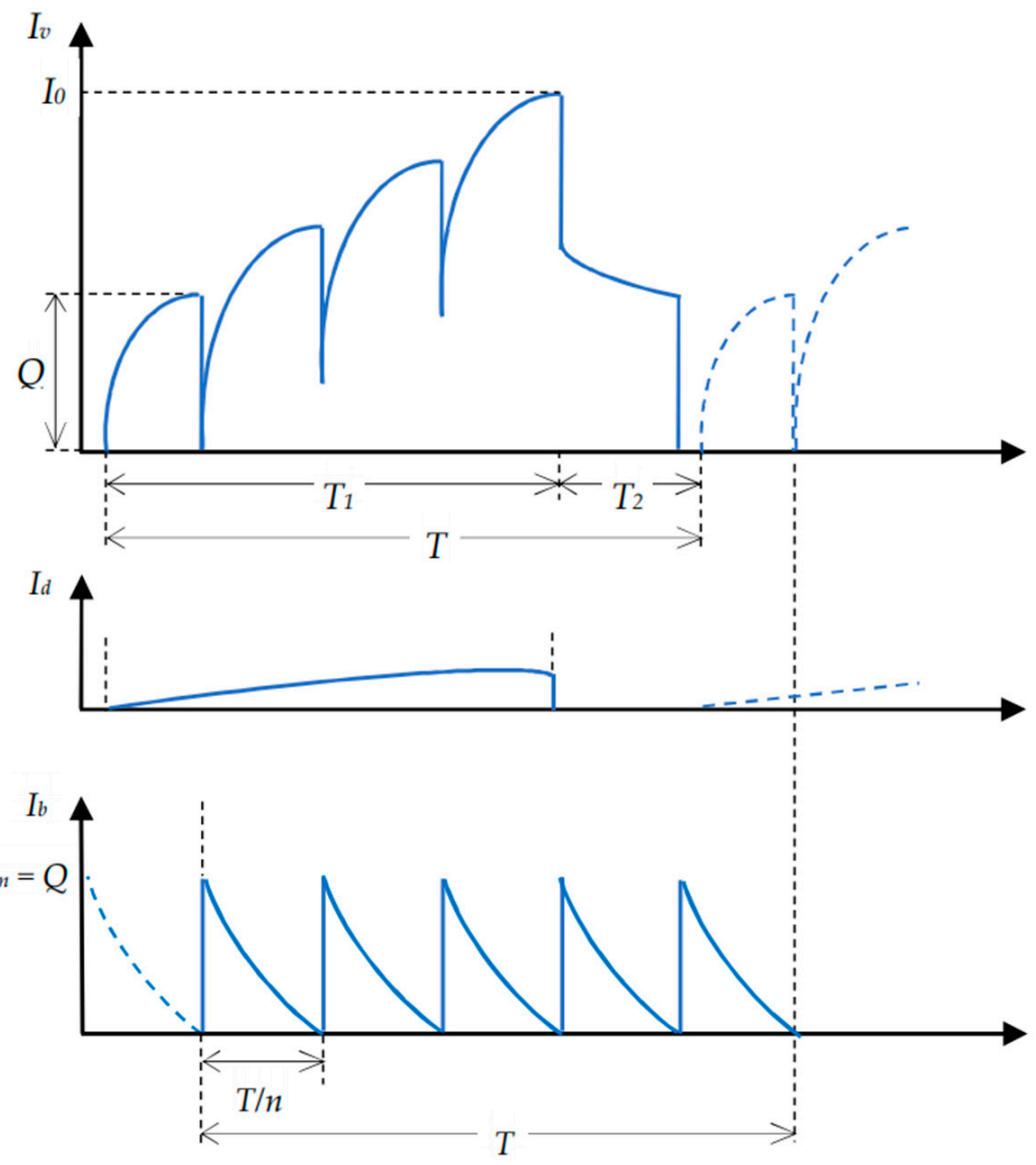

Figure 1. Vendor and buyer inventory with imperfect quality and five deliveries $(n)$ per cycle.

\subsection{Total Annual Cost for the Buyer}

Under a vendor-managed inventory partnership, all the inventory-related costs, such as inventory holding, deterioration, and emission costs in the buyer's facility become the 
vendor's responsibility. Hence, the buyer's total cost $\left(T C_{b}\right)$ only comes from a setup cost for maintaining the partnership as follows:

$$
T C_{b}=\frac{c}{T}
$$

4.2. Total Annual Cost and Emissions for the Vendor

The total production quantity per cycle is $r T_{1}$, in which the rate of good-quality products is $(1-u) r$. The total annual costs owned by or charged to the vendor consist of:

a. A setup cost

The vendor's setup cost is:

$$
\frac{S}{T}
$$

b. An inspection cost

With an inspection cost per unit $\left(i_{c}\right)$, the vendor's inspection cost is:

$$
\frac{i_{\mathcal{c}} r T_{1}}{T}
$$

c. A holding cost

From the illustration in Figure 1 and similarly to Daryanto et al. [11], the vendor' inventory for good-quality products has the following differential equations:

$$
\begin{gathered}
d I_{v 1}\left(t_{1}\right)=((1-u) r-D) d t_{1}-\theta I_{v 1}\left(t_{1}\right) d t_{1}, 0 \leq t_{1} \leq T_{1} \\
d I_{v 2}\left(t_{2}\right)=-D d t_{2}-\theta I_{v 2}\left(t_{2}\right) d t_{2}, 0 \leq t_{2} \leq T_{2}
\end{gathered}
$$

The following boundary conditions are applied:

- $\quad$ At $t_{1}=0, I_{1}(0)=0$

- At $t_{2}=0, I_{2}(0)=I_{0}$

- At $t_{2}=T_{2}, I_{2}\left(T_{2}\right)=0$

Hence,

$$
\begin{gathered}
I_{v 1}\left(t_{1}\right)=\frac{(1-u) r-D}{\theta}\left(1-e^{-\theta t_{1}}\right), 0 \leq t_{1} \leq T_{1} \\
I_{v 2}\left(t_{2}\right)=\frac{D}{\theta}\left(e^{\theta\left(T_{2}-t_{2}\right)}-1\right), 0 \leq t_{2} \leq T_{2}
\end{gathered}
$$

Further, as $I_{v 1}\left(T_{1}\right)=I_{v 2}(0)$,

$$
\frac{((1-u) r-D)}{\theta}\left(1-e^{-\theta T_{1}}\right)=\frac{D}{\theta}\left(e^{\theta T_{2}}-1\right)
$$

Following Misra's approximation [67] and using Taylor's series expansion for $\theta T<<1$, one has

$$
\begin{gathered}
((1-u) r-D) T_{1}\left(1-\frac{1}{2} \theta T_{1}\right)=D T_{2}\left(1+\frac{1}{2} \theta T_{2}\right) \\
T_{1} \approx \frac{D}{(1-u) r-D} T_{2}\left(1+\frac{1}{2} \theta T_{2}\right)
\end{gathered}
$$

Because $T=T_{1}+T_{2}$,

$$
T \approx \frac{T_{2}}{(1-u) r-D}\left((1-u) r+\frac{1}{2} D \theta T_{2}\right)
$$

The inventory of good-quality products is calculated based on Lee and Kim's approach [25]. It considers the original stock during the production and non-production 
periods minus the inventory at the buyer's storage facility that reflects the products that have been delivered from the vendor's storage facility.

$$
I_{v}(t)=\int_{0}^{T_{1}} I_{v 1}\left(t_{1}\right) d t_{1}+\int_{0}^{T_{2}} I_{v 2}\left(t_{2}\right) d t_{2}-n \int_{0}^{T / n} I_{b}(t) d t
$$

Hence, the inventory of good-quality products is

$$
\int_{0}^{T_{1}} \frac{(1-u) r-D}{\theta}\left(1-e^{-\theta t_{1}}\right) d t_{1}+\int_{0}^{T_{2}} \frac{D}{\theta}\left(e^{\theta\left(T_{2}-t_{2}\right)}-1\right) d t_{2}-n\left[\frac{D}{\theta}\left(\frac{1}{\theta}\left(e^{\frac{\theta T}{n}}-1\right)-\frac{T}{n}\right)\right]
$$

The second part of the vendor's inventory illustrates the defective products. From Figure 1,

$$
d I_{d}\left(t_{1}\right)=u r d t_{1}-\theta I_{d}\left(t_{1}\right) d t_{1}, 0 \leq t_{1} \leq T_{1}
$$

For $t_{1}=0, I_{1}(0)=0$; hence,

$$
I_{d}\left(t_{1}\right)=\frac{u r}{\theta}\left(1-e^{-\theta t_{1}}\right), 0 \leq t_{1} \leq T_{1}
$$

Therefore, the inventory of defective products is

$$
\int_{0}^{T_{1}} \frac{u r}{\theta}\left(1-e^{-\theta t_{1}}\right) d t_{1}
$$

Under a vendor-managed inventory partnership, the following inventory at the buyer's storage facility is the vendor's responsibility. During period $T / n$, the inventory function is

$$
I_{b}(t)=\frac{D}{\theta}\left(e^{\theta\left(\frac{T}{n}-t\right)}-1\right), 0 \leq t \leq T / n
$$

and

$$
Q=I_{b}(0)=\frac{D}{\theta}\left(e^{\frac{\theta T}{n}}-1\right)
$$

Hence, the inventory of products at the buyer's storage facility is

$$
\int_{0}^{T / n} \frac{D}{\theta}\left(e^{\theta\left(\frac{T}{n}-t\right)}-1\right) d t
$$

Finally, the vendor's total holding cost per year is:

$$
\frac{h_{v}}{T}\left[\begin{array}{l}
\frac{(1-u) r-D}{\theta} T_{1}+\frac{(1-u) r-D}{\theta^{2}}\left(e^{-\theta T_{1}}-1\right)-\frac{D T_{2}}{\theta}-\frac{D}{\theta^{2}}\left(1-e^{\theta T_{2}}\right) \\
-n\left[\frac{D}{\theta}\left(\frac{1}{\theta}\left(e^{\frac{\theta T}{n}}-1\right)-\frac{T}{n}\right)\right]+\frac{u r T_{1}}{\theta}+\frac{u r}{\theta^{2}}\left(e^{-\theta T_{1}}-1\right)
\end{array}\right]+h_{b} \frac{n}{T}\left(\frac{D}{\theta}\left(\frac{1}{\theta}\left(e^{\frac{\theta T}{n}}-1\right)-\frac{T}{n}\right)\right)
$$

\section{d. Deterioration cost}

Deterioration occurs at the vendor's inventory and the buyer's inventory; however, both are the vendor's responsibility. At the vendor's inventory, the deterioration cost is:

$$
\frac{d_{v}}{T}\left((1-u) r T_{1}-n\left(\frac{D}{\theta}\left(e^{\frac{\theta T}{n}}-1\right)\right)+\left(u r T_{1}-\frac{u r}{\theta}\left(1-e^{-\theta T_{1}}\right)\right)\right)
$$

while the deterioration cost from the inventory at the buyer's storage facility is

$$
d_{b} \frac{n}{T}\left(Q-D \frac{T}{n}\right)=d_{b} \frac{n}{T}\left(\frac{D}{\theta}\left(e^{\frac{\theta T}{n}}-1\right)-\frac{D T}{n}\right)
$$




\section{e. Transportation cost}

With $n$ deliveries per cycle, the transportation cost is

$$
\frac{n}{T}\left(t_{f}+2 d c_{1} t_{v}+d \frac{D}{\theta}\left(e^{\frac{\theta T}{n}}-1\right) w c_{2} t_{v}\right)
$$

The distance, the fuel consumption of empty trucks, and the fuel price have a fixed cost, while the variable cost depends on the quantity per delivery, the product weight, and the fuel consumption per truckload.

\section{f. Carbon emissions cost}

The cap-and-trade system is applied. When $T E>E_{c}$, there are emission costs. On the other hand, the supply chain earns revenue from selling excess quota. $\mathrm{CO}_{2}$ is emitted due to production processes at the vendor's facility, electricity consumption when the products are stored at the vendor's and buyer's storage facilities, and fuel combustion when transporting the products to the buyer's storage facility.

The production emissions are calculated by $r T_{1} P_{e} / T$. The emissions from transportation are

$$
\frac{n}{T}\left(2 d c_{1}+d \frac{D}{\theta}\left(e^{\frac{\theta T}{n}}-1\right) w c_{2}\right) F_{e}
$$

From the defective and good-quality products at the vendor's storage facility, the emissions are

$$
\frac{c_{3} E_{e}}{T}\left[\begin{array}{l}
\frac{(1-u) r-D}{\theta} T_{1}+\frac{(1-u) r-D}{\theta^{2}}\left(e^{-\theta T_{1}}-1\right)-\frac{D T_{2}}{\theta}-\frac{D}{\theta^{2}}\left(1-e^{\theta T_{2}}\right) \\
-n\left[\frac{D}{\theta}\left(\frac{1}{\theta}\left(e^{\frac{\theta T}{n}}-1\right)-\frac{T}{n}\right)\right]+\frac{u r T_{1}}{\theta}+\frac{u r}{\theta^{2}}\left(e^{-\theta T_{1}}-1\right)
\end{array}\right]
$$

From the products at the buyer's storage facility, the emissions are

$$
\frac{c_{3} E_{e} n}{T}\left(\frac{D}{\theta}\left(\frac{1}{\theta}\left(e^{\frac{\theta T}{n}}-1\right)-\frac{T}{n}\right)\right)
$$

The total emissions (TE) are:

$$
\begin{aligned}
r T_{1} P_{e}+\frac{n}{T}\left(2 d c_{1}\right. & \left.+d \frac{D}{\theta}\left(e^{\frac{\theta T}{n}}-1\right) w c_{2}\right) F_{e}+\frac{c_{3} E_{e} n}{T}\left(\frac{D}{\theta}\left(\frac{1}{\theta}\left(e^{\frac{\theta T}{n}}-1\right)-\frac{T}{n}\right)\right) \\
& +\frac{c_{3} E_{e}}{T}\left[\begin{array}{l}
\frac{(1-u) r-D}{\theta} T_{1}+\frac{(1-u) r-D}{\theta^{2}}\left(e^{-\theta T_{1}}-1\right)-\frac{D T_{2}}{\theta}-\frac{D}{\theta^{2}}\left(1-e^{\theta T_{2}}\right) \\
-n\left[\frac{D}{\theta}\left(\frac{1}{\theta}\left(e^{\frac{\theta T}{n}}-1\right)-\frac{T}{n}\right)\right]+\frac{u r T_{1}}{\theta}+\frac{u r}{\theta^{2}}\left(e^{-\theta T_{1}}-1\right)
\end{array}\right]
\end{aligned}
$$

Hence, the total carbon emissions cost per year, according to the cap-and-trade regulations, is

$$
E_{p}\left(T E-E_{c}\right)
$$

Considering all the cost components, the total cost of the vendor (TCv) per year is 


$$
\begin{aligned}
T C_{v}=\frac{s}{T}+\frac{i_{c} r T_{1}}{T} & +\frac{n}{T}\left(t_{f}+2 d c_{1} t_{v}+d \frac{D}{\theta}\left(e^{\frac{\theta T}{n}}-1\right) w c_{2} t_{v}\right)+h_{b} \frac{n}{T}\left(\frac{D}{\theta}\left(\frac{1}{\theta}\left(e^{\frac{\theta T}{n}}-1\right)-\frac{T}{n}\right)\right) \\
& +d_{b} \frac{n}{T}\left(\frac{D}{\theta}\left(e^{\frac{\theta T}{n}}-1\right)-\frac{D T}{n}\right) \\
& +\frac{h_{v}}{T}\left[\begin{array}{l}
\left.\frac{(1-u) r-D}{\theta} T_{1}+\frac{(1-u) r-D}{\theta^{2}}\left(e^{-\theta T_{1}}-1\right)-\frac{D T_{2}}{\theta}-\frac{D}{\theta^{2}}\left(1-e^{\theta} T_{2}\right)\right] \\
-n\left[\frac{D}{\theta}\left(\frac{1}{\theta}\left(e^{\frac{\theta T}{n}}-1\right)-\frac{T}{n}\right)\right]+\frac{u r T_{1}}{\theta}+\frac{u r}{\theta^{2}}\left(e^{-\theta T_{1}}-1\right)
\end{array}\right] \\
& +\frac{d_{v}}{T}\left((1-u) r T_{1}-n\left(\frac{D}{\theta}\left(e^{\frac{\theta T}{n}}-1\right)\right)+\left(u r T_{1}-\frac{u r}{\theta}\left(1-e^{-\theta} T_{1}\right)\right)\right) \\
& +E_{p}\left(\left(\frac{r T_{1} P_{e}}{T}+\frac{n}{T}\left(2 d c_{1}+d \frac{D}{\theta}\left(e^{\frac{\theta T}{n}}-1\right) w c_{2}\right) F_{e}+\frac{c_{3} E_{e} n}{T}\left(\frac{D}{\theta}\left(\frac{1}{\theta}\left(e^{\frac{\theta T}{n}}-1\right)-\frac{T}{n}\right)\right)\right.\right. \\
& \left.+\frac{c_{3} E_{e}}{T}\left[\begin{array}{c}
\left.\left.\frac{(1-u) r-D}{\theta} T_{1}+\frac{(1-u) r-D}{\theta^{2}}\left(e^{-\theta} T_{1}-1\right)-\frac{D T_{2}}{\theta}-\frac{D}{\theta^{2}}\left(1-e^{\theta T_{2}}\right)\right]\right) \\
-n\left[\frac{D}{\theta}\left(\frac{1}{\theta}\left(e^{\frac{\theta T}{n}}-1\right)-\frac{T}{n}\right)\right]+\frac{u r T_{1}}{\theta}+\frac{u r}{\theta^{2}}\left(e^{-\theta T_{1}}-1\right)
\end{array}\right]\right)
\end{aligned}
$$

\subsection{The Supply Chain Cost}

The total cost of the supply chain, considering the expected value of the defective products, is:

$$
\begin{aligned}
E T C=\frac{c}{T}+\frac{s}{T}+ & \frac{i_{c} r T_{1}}{T}+\frac{n}{T}\left(t_{f}+2 d c_{1} t_{v}+d \frac{D}{\theta}\left(e^{\frac{\theta T}{n}}-1\right) w c_{2} t_{v}\right)+h_{b} \frac{n}{T}\left(\frac{D}{\theta}\left(\frac{1}{\theta}\left(e^{\frac{\theta T}{n}}-1\right)-\frac{T}{n}\right)\right) \\
& +d_{b} \frac{n}{T}\left(\frac{D}{\theta}\left(e^{\frac{\theta T}{n}}-1\right)-\frac{D T}{n}\right) \\
& +\frac{h_{v}}{T}\left[\begin{array}{l}
\frac{(1-E[u]) r-D}{\theta} T_{1}+\frac{(1-E[u]) r-D}{\theta^{2}}\left(e^{-\theta T_{1}}-1\right)-\frac{D T_{2}}{\theta}-\frac{D}{\theta^{2}}\left(1-e^{\theta} T_{2}\right) \\
-n\left[\frac{D}{\theta}\left(\frac{1}{\theta}\left(e^{\frac{\theta T}{n}}-1\right)-\frac{T}{n}\right)\right]+\frac{E[u] r T_{1}}{\theta}+\frac{E[u] r}{\theta^{2}}\left(e^{-\theta T_{1}}-1\right)
\end{array}\right] \\
& +\frac{d_{v}}{T}\left((1-E[u]) r T_{1}-n\left(\frac{D}{\theta}\left(e^{\frac{\theta T}{n}}-1\right)\right)+\left(E[u] r T_{1}-\frac{E[u] r}{\theta}\left(1-e^{-\theta} T_{1}\right)\right)\right) \\
& +E_{p}\left(\left(\frac{r T_{1} P_{e}}{T}+\frac{n}{T}\left(2 d c_{1}+d \frac{D}{\theta}\left(e^{\frac{\theta T}{n}}-1\right) w c_{2}\right) F_{e}+\frac{c_{3} E_{e} n}{T}\left(\frac{D}{\theta}\left(\frac{1}{\theta}\left(e^{\frac{\theta T}{n}}-1\right)-\frac{T}{n}\right)\right)\right.\right. \\
& \left.+\frac{c_{3} E_{e}}{T}\left[\begin{array}{c}
\left.\left.\frac{(1-E[u]) r-D}{\theta} T_{1}+\frac{(1-E[u]) r-D}{\theta^{2}}\left(e^{-\theta} T_{1}-1\right)-\frac{D T_{2}}{\theta}-\frac{D}{\theta^{2}}\left(1-e^{\theta} T_{2}\right)\right]\right) \\
-n\left[\frac{D}{\theta}\left(\frac{1}{\theta}\left(e^{\frac{\theta T}{n}}-1\right)-\frac{T}{n}\right)\right]+\frac{E[u] r T_{1}}{\theta}+\frac{E[u] r}{\theta^{2}}\left(e^{-\theta T_{1}}-1\right)
\end{array}\right]\right)
\end{aligned}
$$

\subsection{Methodology and Solution Search}

To solve the problem, we first need to find the optimal delivery frequency $\left(n^{*}\right)$ per cycle that minimizes the expected total cost. Hence, the following procedure is required:

Step 1. Substitute $T_{1}$ and $T$ from Equations (10) and (11) into (30).

Step 2. Use all the known parameters.

Step 3. Set $n=1$.

Step 4. Derive the partial derivative of ETC with respect to $T_{2}$ and find the value of $T_{2}$.

Step 5. Calculate $T_{1}$ and $T$ using Equations (10) and (11) and then the ETC.

Step 6. Repeat Steps 4, 5, and 6 for other possible values of $n$ by incrementally using $n=n+1$ until the minimum ETC is found. The ETC must satisfy the following conditions: $\operatorname{ETC}\left(n^{*}-1\right) \geq \operatorname{ETC}\left(n^{*}\right)$ and $\operatorname{ETC}\left(n^{*}\right) \leq \operatorname{ETC}\left(n^{*}+1\right)$.

Step 7. Calculate $Q^{*}$ from Equation (18) and TE.

\section{Numerical Example and Discussion}

\subsection{Case Illustration}

A case study of a corrugated box manufacturer and its ink vendor, similar to the case study discussed in Daryanto and Krämer [14], is fit to illustrate our model. The corrugated box manufacturer needs ink for its flexo printing machine. A VMI contract is implemented in which the ink vendor has a space in the corrugated box manufacturer's warehouse in which to hold its stock. However, the ink vendor must maintain the stock level in order to 
fulfill the corrugated box production demand. The ink vendor's personnel are on standby in the area and all the equipment and supplies are the vendor's responsibility. Therefore, holding costs are counted for the ink vendor. Moreover, the transportation costs are also the vendor's responsibility. The corrugated box manufacturer has a setup cost for maintaining the partnership per cycle and pays the purchase cost based on its ink usage.

\subsection{Numerical Example}

The following parameters are considered to illustrate the proposed model and to analyze the result. The values are taken from Daryanto et al. [40] and Bai et al. [12]. $D=500,000, r=2,000,000, \theta=0.1, E[u]=0.02, i_{c}=0.5, c=2000, h_{b}=60, d_{b}=600, s=100,000$, $h_{v}=40, d_{v}=400, t_{f}=1000, t_{v}=0.75, d=100, w=0.01, c_{1}=0.27, c_{2}=0.0057, c_{3}=1.44$, $E_{c}=10,000, E_{p}=2.5, F_{e}=2.6 \times 10^{-3}, E_{e}=0.5 \times 10^{-3}$, and $P_{e}=0.01$.

Following the proposed solution procedure and using MAPLE software, the results for different $n$ values were obtained and are presented in Table 2 . When the delivery frequency $(n)$ increases, the delivery lot size $(Q)$ decreases, while the cycle length $(T)$ tends to increase. The optimum $n^{*}$ is 9 when the total cost is $\$ 2.762134503 \times 10^{6}$. Table 2 shows that when the value of $n$ is smaller or greater than 9, the total cost value becomes greater. From this result, we also found the optimal delivery quantity of 4918.0 units with a cycle length of 0.08848 years or a 3.6 day delivery interval.

Table 2. Results for different $n$ values.

\begin{tabular}{cccccc}
\hline $\boldsymbol{n}$ & $\boldsymbol{T}_{\mathbf{2}}$ & $\boldsymbol{T}$ & $\boldsymbol{Q}$ & $\boldsymbol{E T C}$ & $\boldsymbol{T E}$ \\
\hline 1 & 0.04965 & 0.06670 & $33,462.1$ & $3.332846929 \times 10^{6}$ & 5130.027 \\
2 & 0.05640 & 0.07577 & $18,980.4$ & $2.991433130 \times 10^{6}$ & 5134.125 \\
3 & 0.05949 & 0.07993 & $13,340.2$ & $2.874852258 \times 10^{6}$ & 5136.834 \\
4 & 0.06136 & 0.08245 & $10,316.9$ & $2.819920003 \times 10^{6}$ & 5139.069 \\
5 & 0.06268 & 0.08421 & 8428.7 & $2.790695526 \times 10^{6}$ & 5141.081 \\
6 & 0.06369 & 0.08557 & 7136.3 & $2.774629333 \times 10^{6}$ & 5142.964 \\
7 & 0.06452 & 0.08668 & 6195.7 & $2.766188944 \times 10^{6}$ & 5144.764 \\
8 & 0.06522 & 0.08763 & 5480.4 & $2.762553674 \times 10^{6}$ & 5146.505 \\
$9^{*}$ & 0.06585 & 0.08848 & 4918.0 & $2.762134503 \times 10^{6}$ & 5148.202 \\
10 & 0.06642 & 0.08924 & 4464.1 & $2.763967875 \times 10^{6}$ & 5149.864 \\
\hline
\end{tabular}

Note: * indicates the optimum value.

However, the optimum decisions with consideration of costs do not result in the minimum total emissions $\left(T E=5148.202\right.$ ton $\left.\mathrm{CO}_{2}\right)$. Total emissions are proportional to an increase in the frequency of delivery. The minimum total emissions are 5130.027 ton $\mathrm{CO}_{2}$ when $n=1$ and $Q=33,462.1$ units, which is $\$ 570,712.426$ or $17.1 \%$ higher than the minimum total cost. The reduction in $\mathrm{CO}_{2}$ emissions is 18.175 ton $\mathrm{CO}_{2}$, which, according to this example, is valued at $\$ 45.437$. It is a small value that a supply chain will prefer to pay compared with losing a chance to obtain high cost efficiency.

\subsection{Effect of Changes in Carbon Cap-and-Trade Parameters}

Many governments have implemented a cap-and-trade regulation to drive emissions reductions. Hence, we analyze the effect of the changes in the carbon cap-and-trade parameters on the proposed model.

Table 3 shows the effect of changes in emission cap $\left(E_{c}\right)$ and emission price $\left(E_{p}\right)$ values on the decision variables, total cost, and total emissions. The \%CTC and \%CTE present the percentage of changes in the total cost and total emissions, respectively, compared to the original decisions. Further, several insights can be gained:

1. The changes in $E_{c}$ and $E_{p}$ do not change the optimum decisions on the number of deliveries per cycle, the cycle length, and the delivery quantity even when the changes reach $50 \%$. We can say that the effect of the changes is insignificant. 
2. The changes in $E_{c}$ and $E_{p}$ affect the total cost. The higher the emission cap, the lower the total cost because the supply chain is allowed to emit more carbon with less tax. When the emission price increases, the total cost becomes lower because the supply chain can obtain more revenue from selling the excess quota. Moreover, the changes in the emission cap are more meaningful for the supply chain as the percentage of the total cost reduction is higher.

3. However, the changes in $E_{c}$ and $E_{p}$ do not affect the total emissions of the supply chain. Hence, the government must carefully consider the policy because the objective of reducing carbon emissions may require a significant value. Therefore, we present further analysis in Section 5.4 in the case of no carbon cap-and-trade regulation $\left(E_{c}\right.$ and $E_{p}=0$ ) to gain more insight. The analysis shows the optimum decisions when $E_{c}$ and $E_{p}$ are decreased by $100 \%$.

Table 3. Effect of changes in cap-and-trade parameter values.

\begin{tabular}{cccccccccc}
\hline Parameters & Changes & $\boldsymbol{n}$ & $\boldsymbol{T}_{\mathbf{2}}$ & $\boldsymbol{T}$ & $\boldsymbol{Q}$ & $\boldsymbol{E T C}$ & \%CTC & $\boldsymbol{T E}$ & $\%$ CTE \\
\hline \multirow{5}{*}{$E_{C}=10,000$} & $+50 \%$ & 9 & 0.06585 & 0.08848 & 4918.0 & $2.749634503 \times 10^{6}$ & -0.45 & 5148.202 & 0 \\
& $+25 \%$ & 9 & 0.06585 & 0.08848 & 4918.0 & $2.755884412 \times 10^{6}$ & -0.22 & 5148.202 & 0 \\
& $-25 \%$ & 9 & 0.06585 & 0.08848 & 4918.0 & $2.762134503 \times 10^{6}$ & 0 & 5148.202 & 0 \\
& $-50 \%$ & 9 & 0.06585 & 0.08848 & 4918.0 & $2.768384412 \times 10^{6}$ & 0.22 & 5148.202 & 0 \\
$E_{p}=2.5$ & $+50 \%$ & 9 & 0.06585 & 0.08848 & 4918.0 & $2.756069646 \times 10^{6}$ & -0.22 & 5148.202 & 0 \\
& $+25 \%$ & 9 & 0.06585 & 0.08848 & 4918.0 & $2.759102076 \times 10^{6}$ & -0.11 & 5148.202 & 0 \\
& 0 & 9 & 0.06585 & 0.08848 & 4918.0 & $2.762134503 \times 10^{6}$ & 0 & 5148.202 & 0 \\
& $-25 \%$ & 9 & 0.06585 & 0.08848 & 4918.0 & $2.765166795 \times 10^{6}$ & 0.11 & 5148.202 & 0 \\
\hline & $-50 \%$ & 9 & 0.06585 & 0.08848 & 4918.0 & $2.768199360 \times 10^{6}$ & 0.22 & 5148.202 & 0 \\
\hline
\end{tabular}

\subsection{Special Case with the Absence of a Carbon Cap-and-Trade Policy}

A special case of the proposed model is studied to examine a situation in which the carbon cap-and-trade policy does not exist. Here, all the values of the parameters are similar to those of the original case except for the values of $E_{c}$ and $E_{p}$, which are zero. The results are presented in Table 4.

Table 4. Results when the carbon cap-and-trade policy is absent.

\begin{tabular}{cccccc}
\hline $\boldsymbol{n}$ & $\boldsymbol{T}_{\mathbf{2}}$ & $\boldsymbol{T}$ & $\boldsymbol{Q}$ & $\boldsymbol{E T C}$ & $\boldsymbol{T E}$ \\
\hline 6 & 0.06369 & 0.08557 & 7136.4 & $2.786772260 \times 10^{6}$ & 5142.964 \\
7 & 0.06452 & 0.08668 & 6195.8 & $2.778327147 \times 10^{6}$ & 5144.764 \\
$8^{*}$ & 0.06522 & 0.08764 & 5480.5 & $2.762553674 \times 10^{6}$ & 5146.505 \\
9 & 0.06585 & 0.08848 & 4918.0 & $2.774263809 \times 10^{6}$ & 5148.203 \\
10 & 0.06642 & 0.08924 & 4464.2 & $2.776093095 \times 10^{6}$ & 5149.864 \\
\hline
\end{tabular}

Note: * indicates the optimum value.

The above result shows that the new optimum $n$ is 8 with a total cost of $\$ 2.762553674 \times 10^{6}$ and a delivery quantity of 5480.5 units. This result is different from that when a cap-and-trade policy exists. With a lower delivery frequency and larger quantities, the buyer holds more inventory. It is interesting that, without a carbon cap-and-trade policy, the total cost is higher. This may happen when the supply chain cannot sell any excess quota. These results show that the implementation of a cap-and-trade policy may be beneficial for industries.

For $n=9$ (the optimum result in Sections 5.2 and 5.3), TE is higher than the case when a cap-and-trade policy is present. This shows the potential benefit of a carbon cap-and-trade policy in reducing carbon emissions. However, the supply chain will reduce the number of deliveries and increase the stock level to obtain lower costs. Interestingly, the total emissions are lower in the case without a carbon cap-and-trade policy. Hence, the government must 
carefully consider the policy in order to make sure that the objective is achieved because the industry may react accordingly to secure a financial benefit. Awareness and a willingness to create a sustainable environment need to be instilled.

\section{Conclusions}

\subsection{Theoretical Implications}

This paper presents a single-vendor and single-buyer low-carbon supply chain model for deteriorating products with imperfect quality under a VMI. The vendor's operational activities, such as production, storage, and transportation, are taken as sources of carbon emissions. A solution procedure to optimize the production and delivery quantity and the number of deliveries per production cycle was developed. This result confirms what previous studies have derived. Under a VMI partnership, a vendor has a long-term business collaboration and more visibility with respect to demand; however, the total cost of the vendor increases.

The optimum decisions with consideration of the costs of the supply chain do not guarantee the minimum total emissions. The changes in the value of the carbon cap and carbon price do not change the optimum decisions except for the total costs borne by the supply chain. This study also found that the total cost is higher in the case without a carbon cap-and-trade policy. This may happen when the supply chain cannot sell any excess quota. Therefore, the implementation of a cap-and-trade policy may be beneficial for industries. Further, the existence of the carbon cap-and-trade policy does not guarantee an emissions reduction. Hence, the government must carefully consider the policy in order to make sure that the objective is achieved because the industry may react accordingly to secure a financial benefit.

\subsection{Practical Implications}

This research provides optimum decisions in terms of delivery quantity and the number of deliveries per cycle that minimize the total costs when a vendor and a buyer collaborate under a VMI partnership. Further, the proposed model yields the optimum production quantity and production cycle of the vendor. Supply chain managers can use these results to maintain the financial benefit of their business while considering the cap-and-trade regulation. They can adjust the number of deliveries and stock level to make the total costs as low as possible.

\subsection{Limitations and Future Research Topics}

The limitations of this study are as follows. The proposed model considers a constant level of demand. Nowadays, consumers are aware of environmental issues that affect demand patterns. Therefore, we recommended that future studies consider a demand function that depends on the environmental performance of the product [34] or consumers' preferences for low-carbon products [68].

This study used only a cap-and-trade policy. Future research could use other regulations, such as a strict carbon policy, to ensure emissions reductions and compare the effects. Moreover, further analysis of the implications of green technology that reduces emissions levels could be incorporated into future models.

In this paper, we assumed a centralized inventory decision. This is not able to fully show the effect of inventory decisions under the VMI partnership regarding carbon emissions reductions. It would be interesting to investigate the impact of decentralized decisions involving different decision mechanisms, such as the Stackelberg leader-follower model, in further research.

Author Contributions: Conceptualization, methodology, software, writing-original draft preparation, Y.D.; validation, writing-review and editing, R.D.A., Y.D. and P.K.D.; funding acquisition, administration, and corresponding author, R.D.A. All authors have read and agreed to the published version of the manuscript. 
Funding: This work was supported by the Ministry of Education, Culture, Research, and Technology of the Republic of Indonesia (311/E4.1/AK.04.PT/2021).

Institutional Review Board Statement: Not applicable.

Informed Consent Statement: Not applicable.

Data Availability Statement: All data used to validate the proposed model are given in the manuscript.

Conflicts of Interest: The authors declare no conflict of interest.

\section{References}

1. Jeenanunta, C.; Kongtarat, V.; Buddhakulsomsiri, J. A simulation-optimisation approach to determine optimal order-up-to level for inventory system with long lead time. Int. J. Logist. Syst. Manag. 2021, 38, 253-276. [CrossRef]

2. Wang, C.-N.; Dang, T.-T.; Nguyen, N.-A.-T. A Computational Model for Determining Levels of Factors in Inventory Management Using Response Surface Methodology. Mathematics 2020, 8, 1210. [CrossRef]

3. Wang, C.-N.; Nguyen, N.-A.-T.; Dang, T.-T. Solving Order Planning Problem Using a Heuristic Approach: The Case in a Building Material Distributor. Appl. Sci. 2020, 10, 8959. [CrossRef]

4. Damert, M.; Feng, Y.; Zhu, Q.; Baumgartner, R.J. Motivating low-carbon initiatives among suppliers: The role of risk and opportunity perception. Resour. Conserv. Recycl. 2018, 136, 276-286. [CrossRef]

5. Das, C.; Jharkharia, S. Low carbon supply chain: A state-of-the-art literature review. J. Manuf. Technol. Manag. 2018, 29, 398-428. [CrossRef]

6. Gunasekaran, A.; Irani, Z.; Papadopoulos, T. Modelling and analysis of sustainable operations management: Certain investigations for research and applications. J. Oper. Res. Soc. 2014, 65, 806-823. [CrossRef]

7. Taleizadeh, A.A.; Soleymanfar, V.R.; Govindan, K. Sustainable economic production quantity models for inventory systems with shortage. J. Clean. Prod. 2018, 174, 1011-1020. [CrossRef]

8. Wahab, M.; Mamun, S.; Ongkunaruk, P. EOQ models for a coordinated two-level international supply chain considering imperfect items and environmental impact. Int. J. Prod. Econ. 2011, 134, 151-158. [CrossRef]

9. Hariga, M.; As'Ad, R.; Shamayleh, A. Integrated economic and environmental models for a multi stage cold supply chain under carbon tax regulation. J. Clean. Prod. 2017, 166, 1357-1371. [CrossRef]

10. Tiwari, S.; Daryanto, Y.; Wee, H.M. Sustainable inventory management with deteriorating and imperfect quality items considering carbon emission. J. Clean. Prod. 2018, 192, 281-292. [CrossRef]

11. Daryanto, Y.; Wee, H.M.; Widyadana, G.A. Low Carbon Supply Chain Coordination for Imperfect Quality Deteriorating Items Mathematics 2019, 7, 234. [CrossRef]

12. Bai, Q.; Gong, Y.; Jin, M.; Xu, X. Effects of carbon emission reduction on supply chain coordination with vendor-managed deteriorating product inventory. Int. J. Prod. Econ. 2019, 208, 83-99. [CrossRef]

13. Nugroho, A.V.T.A.; Wee, H.M. Supply Chain Coordination under Vendor Managed Inventory System Considering Carbon Emission for Imperfect Quality Deteriorating Items. In Proceedings of the 9th International Conference on Operations and Supply Chain Management, Ho Chi Minh City, Vietnam, 15-18 December 2019.

14. Daryanto, Y.; Krämer, K. Analysis of logistics and supply chain management agility in corrugated box industry. Spektrum Ind. 2016, 14, 53-62. [CrossRef]

15. Kumar, M.G.; Uthayakumar, R. Modelling on vendor-managed inventory policies with equal and unequal shipments under GHG emission-trading scheme. Int. J. Prod. Res. 2019, 57, 3362-3381. [CrossRef]

16. Turken, N.; Geda, A.; Takasi, V.D.G. The impact of co-location in emissions regulation clusters on traditional and vendor managed supply chain inventory decisions. Ann. Oper. Res. 2021. [CrossRef]

17. Astanti, R.D.; Ai, T.J.; Gong, D.-C.; Luong, H.T. Comparison of Two Buyer-Vendor Coordination Models. IOP Conf. Ser. Mater. Sci. Eng. 2018, 319, 012048. [CrossRef]

18. Devy, N.L.; Ai, T.J.; Astanti, R.D. A Joint Replenishment Inventory Model with Lost Sales. IOP Conf. Ser. Mater. Sci. Eng. 2018, 337, 012018. [CrossRef]

19. Dong, Y.; Xu, K. A supply chain model of vendor managed inventory. Transp. Res. Part E Logist. Transp. Rev. 2002, 38, 75-95. [CrossRef]

20. Yao, Y.; Evers, P.T.; Dresner, M.E. Supply chain integration in vendor-managed inventory. Decis. Support Syst. 2007, 43, 663-674. [CrossRef]

21. Zanoni, S.; Mazzoldi, L.; Jaber, M.Y. Vendor-managed inventory with consignment stock agreement for single vendor-single buyer under the emission-trading scheme. Int. J. Prod. Res. 2014, 52, 20-31. [CrossRef]

22. Nie, L.; Xu, X.; Zhan, D. Incorporating transportation costs into JIT lot splitting decisions for coordinated supply chains. J. Adv. Manuf. Syst. 2006, 5, 111-121. [CrossRef]

23. Ertogral, K.; Darwish, M.; Ben-Daya, M. Production and shipment lot sizing in a vendor-buyer supply chain with transportation cost. Eur. J. Oper. Res. 2007, 176, 1592-1606. [CrossRef]

24. Sarkar, B. A production-inventory model with probabilistic deterioration in two-echelon supply chain management. Appl. Math Model. 2013, 37, 3138-3151. [CrossRef] 
25. Lee, S.; Kim, D. An optimal policy for a single-vendor single-buyer integrated production-distribution model with both deteriorating and defective items. Int. J. Prod. Econ. 2014, 147, 161-170. [CrossRef]

26. Bazan, E.; Jaber, M.Y.; Zanoni, S.; Zavanella, L.E. Vendor Managed Inventory (VMI) with Consignment Stock (CS) agreement for a two-level supply chain with an imperfect production process with/without restoration interruptions. Int. J. Prod. Econ. 2014, 157, 289-301. [CrossRef]

27. Sarkar, B.; Shaw, B.K.; Kim, T.; Sarkar, M.; Shin, D. An integrated inventory model with variable transportation cost, two-stage inspection, and defective items. J. Ind. Manag. Optim. 2017, 13, 1975-1990. [CrossRef]

28. Rau, H.; Wu, M.-Y.; Wee, H.-M. Deteriorating item inventory model with shortage due to supplier in an integrated supply chain. Int. J. Syst. Sci. 2004, 35, 293-303. [CrossRef]

29. Pervin, M.; Roy, S.K.; Weber, G.-W. An integrated vendor-buyer model with quadratic demand under inspection policy and preservation technology. Hacet. J. Math. Stat. 2020, 49, 1168-1189. [CrossRef]

30. Ali, S.S.; Barman, H.; Kaur, R.; Tomaskova, H.; Roy, S.K. Multi-Product Multi Echelon Measurements of Perishable Supply Chain: Fuzzy Non-Linear Programming Approach. Mathematics 2021, 9, 2093. [CrossRef]

31. Chan, C.K.; Wong, W.H.; Langevin, A.; Lee, Y. An integrated production-inventory model for deteriorating items with consideration of optimal production rate and deterioration during delivery. Int. J. Prod. Econ. 2017, 189, 1-13. [CrossRef]

32. Sathaye, N.; Horvath, A.; Madanat, S. Unintended impacts of increased truck loads on pavement supply-chain emissions. Transp. Res. Part A Policy Pract. 2010, 44, 1-15. [CrossRef]

33. Jauhari, W.A.; Pamuji, A.S.; Rosyidi, C.N. Cooperative inventory model for vendor-buyer system with unequal-sized shipment, defective items and carbon emission cost. Int. J. Logist. Syst. Manag. 2014, 19, 163-186. [CrossRef]

34. Zanoni, S.; Mazzoldi, L.; Zavanella, L.E.; Jaber, M.Y. A joint economic lot size model with price and environmentally sensitive demand. Prod. Manuf. Res. 2014, 2, 341-354. [CrossRef]

35. Benjaafar, S.; Li, Y.; Daskin, M. Carbon Footprint and the Management of Supply Chains: Insights from Simple Models. IEEE Trans. Autom. Sci. Eng. 2013, 10, 99-116. [CrossRef]

36. Hammami, R.; Nouira, I.; Frein, Y. Carbon emissions in a multi-echelon production-inventory model with lead time constraints. Int. J. Prod. Econ. 2015, 164, 292-307. [CrossRef]

37. Sarkar, B.; Ganguly, B.; Sarkar, M.; Pareek, S. Effect of variable transportation and carbon emission in a three-echelon supply chain model. Transp. Res. Part E Logist. Transp. Rev. 2016, 91, 112-128. [CrossRef]

38. Wangsa, I.D. Greenhouse gas penalty and incentive policies for a joint economic lot size model with industrial and transport emissions. Int. J. Ind. Eng. Comput. 2017, 8, 453-480. [CrossRef]

39. Bouchery, Y.; Ghaffari, A.; Jemai, Z.; Tan, T. Impact of coordination on costs and carbon emissions for a two-echelon serial economic order quantity problem. Eur. J. Oper. Res. 2017, 260, 520-533. [CrossRef]

40. Paul, A.; Pervin, M.; Roy, S.K.; Maculan, N.; Weber, G.-W. A green inventory model with the effect of carbon taxation. Ann. Oper. Res. 2021. [CrossRef]

41. Daryanto, Y.; Wee, H.M.; Astanti, R.D. Three-echelon supply chain model considering carbon emission and item deterioration. Transp. Res. Part E Logist. Transp. Rev. 2019, 122, 368-383. [CrossRef]

42. Wee, H.M.; Daryanto, Y. Imperfect quality item inventory models considering carbon emissions. In Optimization and Inventory Management; Shah, N.H., Mittal, M., Eds.; Springer Nature: Singapore, 2020.

43. Wangsa, I.D.; Tiwari, S.; Wee, H.M.; Reong, S. A sustainable vendor-buyer inventory system considering transportation, loading and unloading activities. J. Clean. Prod. 2020, 271, 122120. [CrossRef]

44. Daryanto, Y.; Wee, H.M. Three-Echelon Green Supply Chain Inventory Decision for Imperfect Quality Deteriorating Items. Oper. Supply Chain Manag. Int. J. 2021, 14, 26-38. [CrossRef]

45. Hasan, R.; Roy, T.C.; Daryanto, Y.; Wee, H.-M. Optimizing inventory level and technology investment under a carbon tax, cap-and-trade and strict carbon limit regulations. Sustain. Prod. Consum. 2021, 25, 604-621. [CrossRef]

46. Marchi, B.; Zanoni, S.; Zavanella, L.; Jaber, M. Supply chain models with greenhouse gases emissions, energy usage, imperfect process under different coordination decisions. Int. J. Prod. Econ. 2019, 211, 145-153. [CrossRef]

47. Kumar, R.S.; Pugazhendhi, S. Information Sharing in Supply Chains: An Overview. Procedia Eng. 2012, 38, 2147-2154. [CrossRef]

48. Azadegan, A.; Dooley, K.J. Supplier innovativeness, organizational learning styles and manufacturer performance: An empirical assessment. J. Oper. Manag. 2010, 28, 488-505. [CrossRef]

49. Bigliardi, B.; Bottani, E.; Galati, F. Open innovation and supply chain management in food machinery supply chain: A case study. Int. J. Eng. Sci. Technol. 2010, 2, 244-255. [CrossRef]

50. Khazanchi, S.; Lewis, M.W.; Boyer, K.K. Innovation-supportive culture: The impact of organizational values on process innovation. J. Oper. Manag. 2007, 25, 871-884. [CrossRef]

51. Stock, G.N.; Greis, N.P.; Fischer, W.A. Firm size and dynamic technological innovation. Technovation 2002, 22, 537-549. [CrossRef]

52. Chesbrough, H. The Logic of Open Innovation: Managing Intellectual Property. Calif. Manag. Rev. 2003, 45, 33-58. [CrossRef]

53. Prabowo, R.; Singgih, M.L.; Karningsih, P.D.; Widodo, E. New Product Development from Inactive Problem Perspective in Indonesian SMEs to Open Innovation. J. Open Innov. Technol. Mark. Complex. 2020, 6, 20. [CrossRef]

54. Yun, J.J.; Zhao, X.; Wu, J.; Yi, J.C.; Park, K.; Jung, W. Business Model, Open Innovation, and Sustainability in Car Sharing Industry-Comparing Three Economies. Sustainability 2020, 12, 1883. [CrossRef] 
55. Pichlak, M.; Szromek, A.R. Eco-Innovation, Sustainability and Business Model Innovation by Open Innovation Dynamics. J. Open Innov. Technol. Mark. Complex. 2021, 7, 149. [CrossRef]

56. Triguero, A.; Fernández, S.; Sáez-Martinez, F.J. Inbound open innovative strategies and eco-innovation in the Spanish food and beverage industry. Sustain. Prod. Consum. 2018, 15, 49-64. [CrossRef]

57. Hervas-Oliver, J.-L.; Sempere-Ripoll, F.; Boronat-Moll, C. Technological innovation typologies and open innovation in SMEs: Beyond internal and external sources of knowledge. Technol. Forecast. Soc. Chang. 2021, 162, 120338. [CrossRef]

58. Brunswicker, S.; Vanhaverbeke, W. Open Innovation in Small and Medium-Sized Enterprises (SMEs): External Knowledge Sourcing Strategies and Internal Organizational Facilitators. J. Small Bus. Manag. 2015, 53, 1241-1263. [CrossRef]

59. de Marco, C.E.; Martelli, I.; di Minin, A. European SMEs' engagement in open innovation When the important thing is to win and not just to participate, what should innovation policy do? Technol. Forecast. Soc. Chang. 2020, 152, 119843. [CrossRef]

60. Chen, Y.; Vanhaverbeke, W.; Du, J. The interaction between internal R\&D and different types of external knowledge sourcing: An empirical study of Chinese innovative firms. RED Manag. 2016, 46, 1006-1023. [CrossRef]

61. Leckel, A.; Veilleux, S.; Dana, L.P. Local Open Innovation: A means for public policy to increase collaboration for innovation in SMEs. Technol. Forecast. Soc. Chang. 2020, 153, 119891. [CrossRef]

62. Kapetaniou, C.; Lee, S.H. Geographical proximity and open innovation of SMEs in Cyprus. Small Bus. Econ. 2019, 52, 261-276. [CrossRef]

63. Fawcett, S.E.; Jones, S.; Fawcett, A.M. Supply chain trust: The catalyst for collaborative innovation. Bus. Horiz. 2012, 55, 163-178. [CrossRef]

64. Richey, R.G.; Roath, A.S.; Whipple, J.M.; Fawcett, S.E. Exploring a governance theory of supply chain integration: Barriers and facilitators to integration. J. Bus. Logist. 2010, 31, 237-256. [CrossRef]

65. Williamson, O.E. Transaction-Cost Economics: The Governance of Contractual Relations. J. Law Econ. 1979, 22, 233-261. [CrossRef]

66. Angulo, A.; Nachtmann, H.; Waller, M.A. Supply chain information sharing in a vendor managed inventory partnership. J. Bus. Logist. 2004, 25, 101-120. [CrossRef]

67. Misra, R.B. Optimum production lot size model for a system with deteriorating inventory. Int. J. Prod. Res. 1975, 13, 495-505. [CrossRef]

68. Liu, M.-L.; Li, Z.-H.; Anwar, S.; Zhang, Y. Supply chain carbon emission reductions and coordination when consumers have a strong preference for low-carbon products. Environ. Sci. Pollut. Res. 2021, 28, 19969-19983. [CrossRef] [PubMed] 